\title{
THE CONJUNCTION OF ART AND LIFE: ONTOLOGY OF THE SITE
}

\section{A B S T R A C T}

Art becoming life and its relative convergence to the ideality of autarky ( $\alpha \dot{\tau} \tau \dot{\alpha} \rho \kappa \varepsilon 1 \alpha)$, implies a maxim which coincides with the emancipatory promise of Art. Neo-Marxist authors have prescribed this maxim to Marx's early works, particularly to the thesis from his Economic and Philosophic Manuscripts of 1844, and elaborated it further on these grounds. This maxim has been applied by many avant-garde movements up to the contemporary moment: Bertold Brecht's political theatre, Guy Debord's situationism, site-specific art, fluxus, Joseph Beuys's social sculpture, etc. The common denominator of all these avant-garde practices is the imperative of an affirmation of their use-value - their realisation at the site of their own production, as opposed to the abstractness of their placement in the world. The site of this production is the site of the very production of sociability. Accordingly, the aim of this paper is to examine the maxim art becoming life in the wake of Badiou's ontology of the site by using the example of the modality of site-specific works in the conditions of contemporaneity. 


\section{LIFE, BEAUTY AND LABOUR ACCORDING TO EARLY MARX}

In his early works, Marx advocated a thesis on the generic foundation of the non-alienated human that reveals itself in the very genericity of his/her being. According to Marx and his texts on estranged labour, the process of human emancipation should lead to the very process of objective production as a realisation of the genericity of a human's being that unfolds as an active species-life (Gattungsleben). Marx maintained that this specific objective labour implies an objectification of a human's species-life as a free expression of universal human life.

The concept of Gattungsleben/wesen ${ }^{1}$ designates a crucial notion for understanding the presuppositions of human emancipation within Marx's early conceptual framework. In some of the texts, such as On the Jewish Question, Marx elucidates the concept of Gattungsleben/wesen in term of essence, positioning the very notion of human as a totality to which a man must "be returned". However, later in the texts regarding communism, Marx highlights the argument that civil society presupposes the principle of individualism: a particular existence is shown to be the ultimate goal in which activity, labour etc. are only the means of such production. In other word, Marx insisted on the axiom of universality that he finds in society, and Marx bounds up this universality of the social (Gattungswesen/leben) with the truth that should be "deduced from the actual forms of existing reality". ${ }^{2}$ For instance, the thesis on social truth that is immanent to a given society/history is present in his early writings, particularly in Letter to Arnold Ruge in Dresden (September 1843), such as when he claims, at the end of the letter, that the social critique must "deduce a true reality from the actual forms of existing reality". Likewise, in Theses on Feuerbach, Marx criticises Feuerbach's conception of human essence as genus. ${ }^{3}$ Taking into account the thesis on truth, which should be "deduced from the actual forms of existing reality", it may become possible to distinguish that Marx does not presuppose any underlying principle of the true society or any human natural essence (genus) to human emancipation: it is neither need (i.e. morality, which masks the fact that nature does not exist), nor natural moment, nor politics. At this point, Badiou's and Marx's theoretical perspectives may be brought to the same plane. ${ }^{4}$

\section{Political vs. Human Emancipation}

Human emancipation presupposes the category of a "species-life" (Gattungsleben) / "species-being" (Gattungswesen). The synthesis between "species-life" (Gattungsleben) and "species-being" (Gattungswesen) (human totality / a real, social human being - axiom of community) "should" be realised as a presupposition of human emancipation. However, human emancipation does not correspond to political or formal juridical emancipation. It is important 
to note that Marx provided a detailed account on the discrepancy between political and human emancipation in the text On the Jewish Question: the political emancipation considers a legal, normative dimension of emancipation, while human emancipation entails emancipation beyond political emancipation. In other words, the legal, juridical conception of emancipation, which affirms the "essence of difference", 5 and human emancipation, which is always supernumerary to the conceptual pairing legal/illegal that Marx finds in the "essence of community", should not be confused.

Political emancipation cannot resolve the problem of alienation, since communism (axiom of community) is not a synonym for the state. According to Marx, political emancipation acknowledges the division of the human animal into a public and private human being. ${ }^{6}$ The realisation of the axiom of community is possible only through the revolutionary temporality by which the social division may be temporarily abolished (equality). From Badiou's standpoint, Marx's conception of political emancipation may be thought of in term of didactic shema $a^{7}$, by which artistic practise is reduced to the public regime of appearances that forms rules (truths) in accordance with the ideal goals of the existing society as a normative standpoint from and by which a particular art comes to be judged as "good" or "bad". From such a standpoint, art is incapable of truth, and, therefore, truth is imposed on art from the outside. As Marx remarked, political emancipation implies the concept of the completion of emancipation. However, human emancipation presupposes a much more complex concept: the realisation of its twofold dimension - a human animal should exist as a particular universal and the particular or individual dimension of the human animal and universal "species-life" should not be understood as being in a conflictual relationship. The universal and the particular are conjoined and their differences erased. As opposed to the individual that appears to be an abstract monad in modern civil society, the concept of "species-being" is not atomised, since it is anchored in the very relation between I and the other.

\section{The Aesthetic Interpretation of "Species-being"}

The aesthetic interpretation of Marx's concept of "species-being" is found in his text on Estranged Labour: "Man therefore also forms objects in accordance with the laws of beauty". ${ }^{8}$ The meaning of Marx's statement is still quite vague to this day. According to Marx, beauty is a property of human although it seems to be a property of things (something beautiful in nature). However, it does not imply that the aesthetic and beauty are (only) subjective. In Marx's philosophical perspective, beauty is that which is simultaneously both objective and the subjective. Beauty is at once a form, when we judge it, and also life, when we feel it: "It is at once our state of being and our creation." Marx, however, tried to free the concepts of beauty and aesthetics 
from their humanist theological attire, and to subordinate them to the socioeconomic realm of examination. The classical moral theological connotations of a "species-being" have now been replaced with the notion of collectivity as the real locus of "species-being".

Therefore, "producing in accordance with the laws of beauty" presupposes nothing other than the free expression of universal (human) life. The object of such labour is the objectification of the species-life of man, states Marx. The task of the process of de-alienation lies therefore in making a human "species-life" into a means of his/her own physical existence, which, in the final analysis, means that labour must be thought of as an end in itself. This conception asserts the use-value of artistic production, or, in other words, the autonomy of the ways of doing and making within the sensory realm. The autonomy of aesthetic experience has nothing to do with the formal aesthetic qualities of an abstract artistic object.

Therefore, the concept of beauty must be thought of as a synthesis between human generic being (Gattungswesen) and her/his real life (Gattungsleben). Beauty, accordingly, implies the living form of a human social life in Marx's conceptual approach. That is to say, the human animal should exist both as a generic being and a generic life - he/she should exist as a particular universal and as a theoretical reflection of the living form of human social life. ${ }^{10}$

\section{ALAIN BADIOU: BEAUTY, SITE AND ARTISTIC TRUTH}

The autonomy of the appearance of truth in art presupposes the appearance of a human (generic humanum) as related to him/herself in the aesthetic object. Therefore, Badiou's conceptualisation of the appearance of truth or the unfolding the generic truth procedure may be bound up with early Marx's explanation of the "objectification of the species-life of a man". ${ }^{11}$ In Badiou's inaesthetics, the promise of human emancipation through art/senses would imply the possibility of incorporating oneself in the temporality of revealing the inhuman subjective generic life.

According to Badiou, the body-of-truth ${ }^{12}$ is the materiality that bears the subjective formalisation. An active body-of-truth, as Badiou maintains, is formalised by the subject of art. The conception of incorporating oneself into a subject of art may be explained through Badiou's theory of two bodies that he developed in the wake of Lacan's theory. The process of human incorporation into a subject of art implies:

1. an incorporation of the human animal and its own organic body (self - pathological incentives and drives) in the symptomal body, or bodyplace-of-the-Other. This symptomal body is, according to Badiou, a 
work of art that bears the universal subject of art in its locality. The universal subject of art is set out by erasure of that "familiar body" (myself) in favour of the body of emancipatory Art (the local instance of the differential point of a truth).

2. an incorporation of this local instance into the generic artistic sequence and, finally, into artistic configuration, which, as Badiou states, is the universal subject of art that is non-empirical, non-organic and brings about the transhistorical and transwordly. ${ }^{13}$

The unfolding the truth(s) through a body of art can take place on the condition that an event is localizable (the site is knowable). Badiou's theory of site is complex, and this complexity derives from Badiou's hypothesis that the site signifies a transition point, or a passage, bridging the being of a situation (void) to the positioning of its post-event truth(s). The site is a paradoxical multiplicity, which is consistent with its situational structure in such a way that it exposes its situation to fundamental inconsistencies. ${ }^{14}$ According to Badiou, in (some) world(s) objects appear, inasmuch as they are atomically structured, and as between these objects there exist relations (or not). Human animals are always in a world, and they exist as its objects as well. Since any object may become a site of appearance of artistic truth and the artistic constitution of the body, a human animal itself may become a site of a universal artistic address. In this process of transforming an object into a site, the object "vanishes without delay", says Badiou. This process is a signal that an event is localised, and at the same time, that a body of art is constituted. This renders Badiou's position anti-humanist as opposed to Marx's early stance. A body is a singular object of and in the world that makes up the appearance of truth in art and as the time/ praxis of configuring to the existing reality.

A body is a specific multiple-being that bears subjective formalism; the notion of formalism does not signify form in the classical philosophical (phenomenological) sense of the term, but rather the process of human emancipation in art itself, inasmuch as it designates an axiomatic of an universal artistic act. ${ }^{15}$ The formalisation of artistic truth always demonstrates its own coherence inasmuch as it is an end in itself, to put it in Marx's words. For instance, the happening (fluxus) as art introduced a new perception of an (artistic) object. The aesthetic newness of this perception comprised of the new ways of doing and making and comprised of the process of removing a singular object (singular inasmuch as it became a site) from ordinary experiences. Any object of a world could become a site for the appearance of the truth, of a free disinterested artistic expression, as that which addresses all (for the body of artistic truth does not presuppose any particular audience). Kantor Tadeusz, a Polish visual artist, for instance, once said, "an object ought to be won over and possessed rather than depicted or shown (...)" ${ }^{16}$ Similarly, Allan Kaprow, an 
American visual artist, developed formal procedures of (non-) art that should render the (aesthetic) experience of "pure immediacy". The Authors of the Fluxus maintained that the "disclosure of self-alienation means to reveal our own scission “ ${ }^{17}$ In 2008 Pedro Reyes, a Mexican contemporary artist, collected 1,527 weapons from residents of Culiacán, a city in western Mexico with a high rate of gun deaths, which were exchanged for electronics. The artist then melted the weapons down into shovels, which were used to plant 1,527 trees.

\section{CONCLUSION: “ARTISTIC LIFE”}

What Marx named the objectification of the species-life of man as a free expression of the universal human life in his (still) humanist endeavour, for Badiou signifies the (self-) organisation of the body on the condition of the localisation of an event: "It is only by working out an organisation for the subjectivizable body that one can hope to 'live', and not merely try to." 18 Therefore, the artistic emancipatory change is possible on account of recognising the process of object-becoming-site. The body of art vanishes as soon as an object-site is marked.

According to Badiou, the self-belonging multiplicity of a site (pure selfcoincidence) concerns nothing other than Beauty itself, inasmuch as "Beauty is in that which is not". ${ }^{19}$ As a result, human emancipation in art presupposes this "Inhumane Beauty", that which exists with a minimal degree of its existence.

On the basis of the above, Badiou's anti-humanist premises - anti-humanist inasmuch as the body of art is constituted on condition of an event - to live artistically, would imply to take as a point of departure the inhuman truths "which oblige us to formalise without anthropologizing". ${ }^{20}$ Therefore, to live artistically involves a radical dehumanization of art, which, in Badiou's terms, signifies the very process of formalising in-human artistic truths. The incorporation of oneself into an artistic sequence, finally, implies a transhuman body and "that a subject takes hold of the divisible body of the human animal". ${ }^{21}$ This is due to the fact that the body provides the material support for the decision making, which, in the final analysis, means to filter the infinite through the two.

Accordingly, to live artistically would mean neither the experience of the pleasure in imaginary relation ("first death" / pathological incentives and drives, pleasure principle or self-preservation) nor its prohibition, that is to say, a sacrifice of enjoyment (bare subordination to the law of the Other, "second death", artistic self-approval in accordance with the law of the Other), but rather reaching the edge of a void, the site that always stands "between two death". The site is the only "place without place" at which the praxis in accordance with and for the sake of the law of Inhuman Beauty - that is to say, an universalizing emancipatory act - and the production of society may become possible. 
Luca Basso, „Gattungswesen and Politics: From the Critique of Hegel's Doctrine of the State to The Holy Family, “ in Marx and Singularity. From the Early Writings to the 'Grundrisse' (Leiden - Boston: Brill, 2012), 26.

Karl Marx, "Marx to Ruge," in Karl Marx, Friedrich Engels, Early Writings, (trans. Rodney Livingstone and Gregor Benton) (London: Penguin Books, 1992), 208.

Ibid., 423.

Cf. Patric McGee, Theory and the Common from Marx to Badiou (New York: Palgrave Macmillan, 2009).

Karl Marx, "On the Jewish Question,“ in Karl Marx, Friedrich Engels, Early Writings, 221. Ibid., 222.

Alain Badiou, Handbook of Inaesthetics (Stanford: Stanford University Press, 2005), 3.

Karl Marx, "Estranged Labour,“ in Karl Marx, Friedrich Engels, Early Writings, 329.

Mikhail Lifshitz, The Philosophy of Art of Karl Marx (New York: Pluto Press, 1976), 96.

Leonard P. Wessell, „The Aesthetics of Living Form in Schiller and Marx“, 196.

Karl Marx, "Estranged Labour," in Early Writings, 329.

Alain Badiou, ,Book VII: What is a Body,” in Logics of Worlds, Being and Event II (London-New Delhi-New York-Sydney: Bloomsbury, 2013), 453.

Alain Badiou, „Lacan,” in Logics of Worlds, Being and Event II, 479.

A. J. Barlett, "Site," in Badiou and Plato. An Education by Truths (Edunburgh: Edinburgh University Press, 2011), 71.

Alain Badiou, „The Infinite,“ in The Century (MA, Cambridge: Polity Press), 162.

Alain Badiou, Bernard Blistene, Yann Chateigne (eds.) „Theater Happening 1967,“ in A Theater without Theater (Barcelona: Museu D'Art Contemporani de Barcelona (MACBA), 2008), 120.

Gino di Maggio, „Fluxus - Kunst als individuelle Revolution Oder Utopie als Gewerbe?,” Flash Art and Heute Kunst, No. 16 (1976): 14-15.

For more regarding the (five) conditions required for the effective existence of a body, see Alain Badiou, „Bodies and Organs of the Matheme,” in Logics of Worlds, Being and Event II, 474.

Alain Badiou, „Ontology of the Site,” Logics of Worlds, Being and Event II, 466.

Alain Badiou, „The Joint Disappearances of man and God,“ The Century, 178.

Alain Badiou, „Lacan,” in Logics of Worlds, Being and Event II, 481. 
Badiou, Alai. Bernard Blistene, Yann Chateigne (eds.), A Theater without Theater. Barecelona: Museu D'Art Contemporani de Barcelona (MACBA), 2008.

Badiou, Alain. Philosophy and the Event. MA: Cambridge, Polity Press, 2013.

Badiou, Alain. Being and Event. London - New York: Continuum, 2012.

Badiou, Alain. Handbook of Inaesthetics. Stanford: Stanford University Press, 2005.

Badiou, Alain. Logics of Worlds, Being and Event II. London - New Delhi -New York - Sydney, 2013.

Badiou, Alain. Polemics. London - New York: Verso, 2006.

Badiou, Alain. The Century. MA: Cambridge, Polity Press, 2007.

Barlett, A. J. Badiou and Plato. An Education by Truths. Edunburgh: Edinburgh University Press, 2011.

Basso, Luca. Marx and Singularity. From the Early Writings to the 'Grundrisse'. LeidenBoston: Brill, 2012.

Gino di Maggio.,,Fluxus - Kunst als individuelle Revolution Oder Utopie als Gewerbe?.” Flash Art and Heute Kunst, No. 16 (1976): 14-15.

Lifshitz, Mikhail. The Philosophy of Art of Karl Marx. New York: Pluto Press, 1976.

Marx, Karl and Friedrich Engels. Early Writings, (trans. Rodney Livingstone and Gregor Benton). London: Penguin Books, 1992.

Meillassoux, Quentin. „History and Event.“ Parrhesia no. 12.(2011).

Potts, Alex, „Writing the Happening: The Aesthetics of Nonart.“ In Eva Meyer-Hermann, Andrew Perchuk and Stephanie Rosenthal, Art as Life,20-34. London: Thames \& Hudson, 2008.

Wessell, P. Leonard. „The Aesthetics of Living Form in Schiller and Marx.“ The Journal of Aesthetics and Art Criticism, Vol. 37. No. 2. (1978):189-201. 


\section{'UČENJE OD DETROITA?' \\ OD MATERIJALIZOVANIH SNOVA DO GORKOG BUĐENJA ESTETIKE OKO DOTRAJALIH TRŽNIH CENTARA \\ Zoltán Somhegyi}

Tržni centri su bili i još uvek su naročito popularni jer su prvi izgrađeni 1950-ih. Zanimljivo, i njihovi česti posetioci i njihovi najveći kritičari ih vide kao materijalizaciju sna potrošačkog društva. Oni se tako često smatraju gotovo 'hramovima' konzumerizma, gde aktivnost 'kupovine' zamenjuje druge, tradicionalnije oblike društveno-kulturnog angažmana. U poslednjih nekoliko godina možemo iskusiti sve veće interesovanje za dokumentacijom propalih centara sa melanholično-nostalgičnog stanovišta u sanjive vizije koje u nekim slučajevima čine slike sličnim klasičnom predstavljanju antičkih ruševina. Da li je to samo slučajnost, ili postoji paralela između uvažavanja ostataka hramova antike i ruševina hramova konzumerizma? U slučaju da da, šta onda možemo da naučimo od pokušaja estetizacije ovog propadanja? Ono što ove serije umetničkih dela mogu otkriti o našem sadašnjem stanju i pristupu prostoru, zabavi, konzumaciji i životu? Ja dovodim u svom ispitivanju neka razmatranja o Detroitu, ne (samo) o samom gradu, koji je postao referentna tačka, a ponekad čak i "igralište" za analizu savremenog propadanja, već i Detroitu kao fenomenu ili simbolu, kao i neka razmatranja na osnovu ponovnog čitanja prekretnice knjige Venturija, Brauna i Izenura.

KLJUČNE REČI: RUŠENJE I NJEGOVO PREDSTAVLJANJE, KLASIČNE I “SAVREMENE” RUŠEVINE, ESTETIKA PROPADANJA, TRŽNI CENTRI, IZGRAĐENO NASLEĐE I OČUVANJE

\section{PREMA POST-DIGITALNOJ ESTETICI}

\section{Anna Daudrich}

Tokom proteklih decenija, digitalna tehnologija i mediji su se čvrsto integrisali u skoro svim oblastima savremene kulture i društva. U tom kontekstu, internet, kompjuteri i mobilni telefoni se više ne smatraju proizvodima novih medija, već se uzimaju zdravo za gotovo. Sa ovom pozadinom na umu, ovaj rad predlaže uzimanje post-digitalnog pogleda na današnje medijsko društvo. Koncept 'post-digitalno' odnosi se na estetiku koja više ne posmatra digitalnu tehnologiju kao revolucionarnu pojavu, već kao normalan aspekt svakodnevnog života ljudi. Tačnije, postdigitalna estetika se bavi okruženjem gde je digitalna tehnologija postala tako uobičajena, da se njeno postojanje često ne priznaje. Na osnovu analize savremenih umetničkih dela i prakse inspirisane svoje okoline, ovaj rad ima za cilj da dovede te fenomene u svest koja je postala neprimetna u savremenom digitalnom okruženju. U tu svrhu, ova istraga prevazilazi formalnoestetske analize, već se fokusira na istragu o receptivnom aktu. Konkretno, post- digitalna estetika nastoji da opiše i analizira promenljive oblike percepcije pod uticajem povećane digitalizacije okoline. U kontekstu ove analize, estetika se stoga razume ne kao cilj sama po sebi već kao sredstvo da se poboljša razumevanje savremene digitalne kulture.

KLJUČNE REČI: POST-DIGITAL, DIGITALNA TEHNOLOGIJA, ESTETIKA, PROMENJENO ISKUSTVO PERCEPCIJE

KONJUNKCIJA UMETNOSTI I ŽIVOTA: ONTOLOGIJA MESTA

\section{Bojana Matejić}

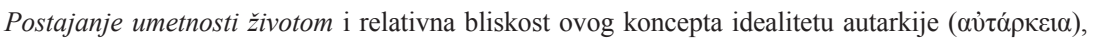
implicira maksimu koja koincidira sa emancipatorskim obećanjem umetnosti. Autori neomarksističkog kruga su pripisali ovu maksimu, po svemu sudeći, Marksovim ranim radovima, naročito određenom setu teza iz njegovih Ekonomsko-filozofskih rukopisa iz 1844. i elaborirali je, dalje, na ovim osnovama. Ova maksima je bila primenjena u mnogim avangardnim praksama do danas: Brehtovo političko pozorište, Deborov situacionizam, specifična mesta (site-specific), flukus, socijalna skulptura Jozefa Bojsa, itd. Zajednički imenitelj svih ovih avangardnih praksi može biti označen imperativom afirmacije njihove upotrebne vrednosti - njihove realizacije na mestu vlastite proizvodnje, spram apstraktnosti njihovog postavljanja u svet. Mesto ove proizvodnje jeste mesto same proizvodnje društvenosti. Shodno tome, cilj ovog rada jeste preispitivanje maksime o postajanju umetnosti životom, u svetlu Badiouove ontologije mesta i na primeru modaliteta radova specifičnih mesta u uslovima savremenosti. 